\title{
Wacana Nasionalisme Dalam Novel Penakluk Badai Karya Aguk Irawan Mn
}

\author{
Khadijah \\ IAIN Palangka Raya \\ khadijah7778@gmail.com
}

\begin{abstract}
Nationalism is a crucial issue in this republic, where nationalism does not have function as unity tool, because of less carrying to Indonesia itself and there are a few people or groups who underline the nationalism for their own importance, and also because of the pancasila fading spirit which then breinging this nation into separation and all of others issues. A moslem literate Aguk Irawan MN, spent his idea about nationalism phenomenon through novel entitled Penakluk Badai the novel took a setting at rising and base of the nation of Indonesia on pre-independence period and telling about how were the national movement started by the Islamic leader. The method of this study was discourse analisys method based on Halliday model, where this model involved three units of study such as discourse site, discourseinvolvement, and discourse mode. So hten the result of the writer's study to three analysis unit of Halliday model were the discourse site related to the natives' education an the fight to colonialism.
\end{abstract}

Keywords : Discourse, Nationalism and Novel

\section{A. Pendahuluan}

Pada era serba modern dan serba terbuka, paham nasionalisme semakin terkikis oleh paham globalisme. Sebagaimana dikatakan oleh Grendi Hendrastomo $^{1}$ dalam jurnalnya yang berjudul Nasionalisme Vs Globalisasi bahwa diaspora (persebaran) globalisasi yang pesat merupakan penyebab utama kemerosotan rasa nasionalisme. ${ }^{2}$ Dalam perkembangannya, nasionalisme di Indonesia dipengaruhi oleh konflik antargolongan dan berbagai kepentingan personal lainnya. Dalam perkembangannya terakhir ini menurut penulis, nasionalisme tidak lagi berfungsi sebagai alat pemersatu, kerena kurangnya rasa memiliki terhadap bangsa Indonesia dan ada beberapa pihak maupun kelompok yang mengatasnamakan nasionalisme untuk kepentingannya, serta lunturnya

\footnotetext{
${ }^{1}$ Grendi Hendrastomo adalah staf pengajar Program Studi Pendidikan Sosiologi Fakultas Ilmu Sosial dan Ekonomi Universitas Negeri Yogyakarta.

${ }^{2}$ Grendi Hendrastomo, Nasionalisme Vs Globalisasi, DIMENSIA Volume I No. 1, Maret 2007, h. 1 .
} 
semangat dari pancasila yang pada gilirannya membawa bangsa pada perpecahan dan berbagai isu negatif lainnya.

Seorang sastrawan kelahiran Lamongan bernama Aguk Irawan MN telah menulis sebuah novel berjudul Penakluk Badai. Kehadiran novel ini seolah sebagai oase ditengah kenasionalismean yang mulai terkikis. Dalam novel ini Aguk Irawan menuangkan gagasannya tentang nasionalisme dalam bentuk novel biografi tokoh nasional sekaligus ulama yaitu K.H.Hasyim Asy'ari. Berbeda dengan penulis lainnya yang menulis biografi dengan bahasa ilmiah, Aguk justru memilih bahasa sastra.

Novel merupakan media komunikasi, yaitu alat atau sarana yang digunakan oleh komunikator (penulis) untuk menyampaikan pesan kepada komunikan (pembaca). Hal ini karena novel memiliki fungsi sebagaimana fungsi komunikasi. Adapun fungsi komunikasi yaitu memberikan informasi, mendidik, menghibur, dan mempengaruhi. ${ }^{3}$ Dengan demikian, selain dapat dikategorikan sebagai media komunikasi novel juga dapat dikategorikan sebagai salah satu media yang dapat mewacanakan sesuatu atas dasar interpretasi penulis dalam melihat fenomena yang terjadi di masyarakat.

Penelitian ini membahas hal yang berkaitan dengan sastra dan sejarah, dengan objek kajiannya wacana nasionalisme dalam novel Penakluk Badai karya Aguk Irawan M.N. Novel Penakluk Badai pada hakekatnya adalah novel sejarah, meskipun oleh pengarangnya tidak diberi lebel sejarah. Melalui novel Penakluk Badai, pengarang mengajak pembaca untuk belajar dari sejarah masa lalu. Mengacu pada latar belakang penelitian di atas, maka penelitian ini berfokus pada isu tentang wacana nasionalisme dalam novel Penakluk Badai karya Aguk Irawan MN.

\section{B. Kajian Pustaka}

Dalam Kamus Besar Bahasa Indonesia, wacana adalah komunikasi verbal, percakapan, keseluruhan tutur merupakan satu kesatuan bahasa terlengkap yang direalisasikan dalam bentuk karangan atau laporan utuh, seperti novel, buku,

\footnotetext{
${ }^{3}$ Onong Udjana Effendy, Ilmu Teori dan Filsafat Komunikasi, Bandung: Citra Aditya Bakti, 2000, h. 55.
} 
artikel, pidato atau khotbah. ${ }^{4}$ Dalam pengertian yang lebih sederhana wacana berarti cara objek atau ide diperbincangkan secara terbuka kepada publik sehingga menimbulkan pemahaman tertentu yang tersebar luas. Teori wacana menjelaskan sebuah peristiwa yang terjadi seperti terbentuknya sebuah kalimat atau pernyataan, sehingga dinamakan dengan analisis wacana. ${ }^{5}$

Sementara itu, secara istilah nasionalisme memiliki pengertian yang beragam. Namun dari berbagai pengertian tersebut, para ahli hanya berbicara tentang paham, ideologi, negara, dan kebangsaan. Seperti yang dikatakan oleh Sukarno dalam bukunya yang berjudul "Pemikiran Politik dan Kenyataan Praktek" bahwa nasionalisme adalah suatu konsep atau paham ${ }^{6}$ kebangsaan, di mana kesetiaan individu diserahkan sepenuhnya kepada negara. ${ }^{7}$ Untuk itu, pemahaman tentang nasionalisme dapat dibedakan antara nasionalisme dalam arti sempit dan dalam arti luas. ${ }^{8}$ Dalam melaksanakan kerja sama dengan negara lain, hal yang diutamakan adalah persatuan dan kesatuan bangsa, kepentingan dan keselamatan bangsanya, serta tetap memandang bangsa lain sederajat dan menghormatinya sebagaimana bangsanya sendiri.

Ikatan nasionalisme ini semakin jelas ketika dilihat dalam firman Allah SWT:

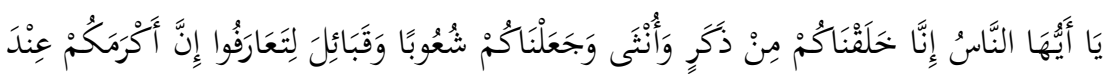

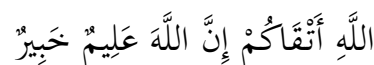

Terjemahnya:

"Hai manusia, Sesungguhnya Kami menciptakan kamu dari seorang lakilaki dan seorang perempuan dan menjadikan kamu berbangsa - bangsa dan bersuku-suku supaya kamu saling kenal-mengenal. Sesungguhnya orang yang paling mulia diantara kamu disisi Allah ialah orang yang paling taqwa diantara kamu. Sesungguhnya Allah Maha mengetahui lagi Maha Mengenal.", 9

\footnotetext{
${ }^{4}$ Departemen Pendidikan Nasional, Kamus Besar Bahasa Indonesia, Edisi ke 3, Jakarta:Persero Balai Pustaka, 2005, h. 1264.

${ }^{5}$ Ibid, h. 11.

${ }^{6} \mathrm{R}$ Suyoto Bakir dan Sigit Suryanto, Kamus Lengkap ..., h. 412. Paham adalah pandangan, pendapat, pikiran, haluan, mengerti benar, tahu benar, pandai dan mengerti benar tentang sesuatu hal.

${ }^{7}$ Sukarno, Pemikiran Politik dan Kenyataan Praktek, Jakarta:CV.Rajawali, 1988, h. 37.

${ }^{8}$ Ihwal Nilai Nasionalisme dan Buku Elektronik serta Silabus, Perpustakaan Universitas Pendidikan Indonesia, pdf 2/14, h. 10-11. (online pada tanggal 24 Januari 2013).

${ }^{9}$ Q.S. Al-Hujurat [49]: 13.
} 
Dalam Al-Qur'an kata sya 'b disebut sekali dalam bentuk plural, yakni syu'ub sebagaimana dalam QS. al-Hujurat ayat 13. Pada mulanya kata tersebut bermakna cabang dan rumpun, sebab bangsa sesungguhnya merupakan suatu rumpun kelompok kabilah tertentu yang tinggal di wilayah tertentu. Suatu bangsa terbentuk biasanya karena ada unsur-unsur persamaan, seperti asal-usul keturunan, sejarah, suku, ras, cita-cita meraih masa depan. ${ }^{10}$

Dalam buku Pendidikan Kewarganegaraan untuk Mahasiswa, disebutkan ada tiga prinsip nasionalisme. ${ }^{11}$ Pertama,prinsip kebersamaan. Penerapan prinsip kebersamaan dalam kehidupan sehari-hari menuntut setiap warga negara agar memiliki sikap "pengendalian diri" untuk mengarahkan aktivitasnya menuju kehidupan yang selaras, serasi dan seimbang.nilai kebersamaan menuntut setiap warga negara untuk menempatkan kepentingan bangsa dan negara di atas kepentingan pribadi atau golongan. Kedua, prinsip persatuan dan kesatuan. Prinsip persatuan dan kesatuan ini merujuk pada sila persatuan Indonesia yang utuh dan tidak terpecah belah atau bersatuannya bermacam-macam perbedaan suku, agama, dan lain-lain yang berada di wilayah Indonesia. Persatuan ini terjadi karena didorong keinginan untuk mencapai kehidupan kebangsaan yang bebas dalam wadah negara yang merdeka dan berdaulat, memajukan kesejahteraan umum, dan mencerdaskan kehidupan bangsa, serta mewujudkan perdamaian abadi. Ketiga, prinsip demokratis. Prinsip demokrasi/demokratis memandang bahwa setiap warga negara mempunyai kedudukan, hak, dan kewajiban yang sama. ${ }^{12}$ Karena hakikat semangat kebangsaan adalah adanya tekad untuk hidup bersama yang mengutamakan kepentingan bangsa dan negara yang tumbuh dan berkembang dari bahwa untuk bersedia hidup sebagai bangsa yang bebas, merdeka, bersatu berkedaulatan, adil, dan makmur.

Sementara itu, novel adalah bentuk prosa baru yang melukiskan sebagian kehidupan pelaku utamanya yang terpenting, paling menarik, dan mengandung

\footnotetext{
${ }^{10}$ Abdul Mustaqim, Bela Negara dalam Perspektif Al-Qur'an (Sebuah Tranformasi Makna Jihad), Analisis Volume XI, Nomor 1, Juni 2011, h. 114.

${ }^{11}$ Srijanti dkk, Pendidikan Kewarganegaraan untuk Mahasiswa, Yogyakarta:Graha Ilmu, 2009, h. 25-26.

${ }^{12}$ Syahrial dkk, Membangun Karakter dan Kepribadian Melalui Pendidikan Kewarganegaraan, h. 112.
} 
konflik. Konflik atau pergulatan jiwa tersebut mengakibatkan perubahan nasib pelaku, dan novel memiliki sifat yang lebih realisme dibandingkan roman. ${ }^{13}$ Umumnya novel bercerita tentang kehidupan sehari-hari dan mengungkap aspek kemanusiaan yang disajikan lebih mendalam. Dalam Kamus Besar Bahasa Indonesia novel adalah karangan prosa yang panjang mengandung rangkaian kehidupan seseorang dengan orang yang ada disekelilingnya dengan menonjolkan watak dan sifat setiap pelaku. ${ }^{14}$

Berdasarkan paparan di atas, maka wacana nasionalisme dalam novel yang penulis maksud ialah bagaimana penulis (komunikator) mengkomunikasikan isu nasionalisme melalui tulisannya (teks novel) kepada pembaca (komunikan). Hal ini, akan penulis bongkar dengan metode analisis wacana model Halliday. Adapun model ini mencakup tiga unsur, yaitu medan wacana, pelibat wacana, dan mode wacana.

\section{Metode Penelitian}

Dalam penelitian ini penulis menggunakan pendekatan analisis wacana model Halliday. Untuk menganalisis sebuah teks Halliday menggunakan bahasa sebagai semiotika sosial. Bahasa sebagai semiotik sosial berarti menafsirkan bahasa dalam konteks sosiokultural tempat kebudayaan itu ditafsirkan dalam terminologis semiotik sebagai sebuah sistem informasi. Menurut Halliday bahasa itu tidak berisi kalimat-kalimat, tetapi bahasa itu berisi teks atau wacana, yakni pertukaran makna dalam konteks interpersonal. ${ }^{15}$

Halliday membangun suatu kerangka kerja yang memungkinkan untuk membedah interaksi antara teks dan situasi yang didasarkan pada tiga konsep, yakni medan wacana, pelibat wacana dan mode wacana. ${ }^{16}$ Dengan pendekatan tersebut penulis berharap dapat menggambarkan realitas tentang wacana nasionalisme yang dikonstruksikan oleh Aguk Irawan MN dalam novel Penakluk

\footnotetext{
${ }^{13}$ Retno Purwandari dan Qoni'ah, Buku Pintar Bahasa Indonesia, Yogyakarta:Familia, 2012, h. 140-141.

${ }^{14}$ Departemen Pendidikan Nasional, Kamus Besar..., h. 788.

${ }^{15}$ Anang Santoso. 2006. Jejak Halliday dalam Linguistik Kritis dan Analisis Wacana Kritis. Artikel. Jurnal Bahasa dan Seni Tahun 36, Nomor 1, Februari 2008. Terarsip di, http://sastra.um.ac.id/wp-content/uploads/2009/10/Jejak-Halliday-dalam-Linguistik-Kritis-danAnalisis-Wacana-Kritis-Anang-Santoso.pdf, (online: Senin, 24 Maret 2014).

${ }^{16}$ Rachmat Kriyantono, Teknik...h. 259.
} 
Badai. Adapun metode Analisis wacana model Halliday ini mencakup tiga konsep yaitu : (1). Medan wacana (field of discourse) : Tindakan sosial yang sedang terjadi atau dibicarakan, aktivitas di mana para pelaku terlibat di dalamnya, serta praktik-praktik yang terlihat dalam teks. (2). Pelibat wacana (tenor of discourse) : Pihak-pihak pembicara dan sasaran yang terlibat dalam pembicaraan serta kedudukan dan hubungan antar mereka. Termasuk menunjuk pada orang-orang yang dicantumkan dalam teks, sifat orang-orang itu, kedudukan dan peranan mereka. Dengan kata lain, siapa saja yang dikutip dan bagaimana sumber itu digambarkan sifatnya. (3). Mode wacana (mode of discourse) : Pilihan bahasa masing-masing media, termasuk gaya bahasa yang digunakan bersifat eksplanatif, deskriptif, persuasif, hiperbolis, dan lainnya serta bagaimana pengaruhnya. ${ }^{17}$

\section{Pembahasan}

Berdasarkan hasil analisis penulis terhadap novel Penakluk Badai, terdapat dua medan wacana yang digambarkan oleh Aguk Irawan MN.

Salah satu medan wacana yang berkaitan dengan nasionalisme digambarkan oleh Aguk Irawan MN melalui perjuangan dalam ranah pendidikan. Perjuangan untuk mencapai kemerdekaan adalah dengan pendidikan, pendidikan akan menyadarkan bangsa tentang penjajahan dan pentingnya merdeka. Dengan pendidikanlah akan lahir jiwa nasionalisme dan kebangkitan nasional. Hal itu dapat dilihat pada deskripsi dialog berikut:

"Menurut Hasyim, kira-kira bagaimana cara kita mulai berbuat kepada negeri ini?", "Maaf, kawula merasa kiai lebih paham tentang ini", jawab Hasyim pendek. "Dengarkan bagus Hasyim. Kita harus mencerdaskan anak bangsa. Kelak, dengan ilmu pengetahuan, mereka sadar bahwa negeri ini sedang terjajah. Dan pada akhirnya memanggul senjata bagi mereka adalah pilihan. Kalau kita buru-buru harus memanggul senjata, saya khawatir penduduk negeri ini semakin banyak jadi korban, mati dengan cara konyol". "Inggih, kiai. Kawula setuju". "kowe ngerti bagus. Dalam kaedah fiqih disebutkan, al-mutta'adi afdhal min al-Qashir (amal ibadah yang membawa dampak lebih luas itu lebih utama dari yang hanya terbatas)". "Inggih kiai, maaf kalau kawula tidak salah memahami bahwa Imam Ghazali mengungkapkan pula, al-Naf al-Muta'addi a'zham min naf al-Qashir, ibadah yang memberi manfaat meluas lebih baik dari yang membawa manfaat pada dirinya sendiri," balas Hasyim, memberi

\section{${ }^{17}$ Ibid,.}


dukungan pada kiai, bahwa perjuangan dengan jalur pendidikan adalah segalanya." 18

Kutipan dialog di atas menggambarkan pendapat kiai tentang pendidikan sebagai upaya perjuangan menyadarkan masyarakat pribumi tentang penjajahan. Pendidikan sangatlah penting, karena dengan pendidikan maka rakyat akan mengerti dan berpandangan luas terhadap keadaan bangsanya, sehingga akan berfikir tentang kemajuan dan kemerdekaan bangsanya.

Ketika sebagian kecil bangsa Indonesia sudah mulai bersentuhan dengan pendidikan modern pada pertengahan abad ke-19, sedikit demi sedikit, terbuka wawasan berfikir bangsa Indonesia. Dari kalangan rakyat Indonesia terdidik yang jumlahnya masih terbatas itu rasa kebangsaan atau nasionalisme dan kesadaran untuk bersatu dalam perjuangan mulai muncul dan disebarluaskan. Pendidikan ternyata begitu besar pengaruhnya untuk membuka fikiran dan kesadaran akan rasa persatuan, rasa kebangsaan, dan rasa kecintaan pada tanah air. Kalangan terdidiklah yang mampu merintis rasa kebangsaan atau nasionalisme ini pada masa Kebangkitan Nasional 1908. Di awal abad ke-20, dapat dikatakan fase pertama tumbuhnya nasionalisme bangsa Indonesia. ${ }^{19}$

Selain itu medan wacana yang berkaitan dengan pendidikan juga dapat dilihat pada kutipan berikut:

"Perkembangan pendidikan dengan sistem madrasah di Tebuireng membuat tokoh-tokoh muda cemerlang, seperti Soekarno dan Hatta,datang berkunjung. Mereka datang untuk membicarakan masalah kebangsaan. Pada tahun 1921, datang pula Tan Malaka dan Semaun (wakil ISDV) ke tebuireng. Dari pertemuan singkat itulah diperoleh kesepakatan bahwa mereka akan sama-sama berjuang mencerdaskan rakyat Indonesia,...20

Kutipan di atas mendekripsikan tentang kesepakatan yang diperoleh dari pertemuan para pejuang, yaitu Soekarno, Tan Malaka, dan K.H. Hasyim Asy'ari. Dari pertemuan tersebut diperoleh kesepakatan bahwa mereka akan bersamasama berjuang mencerdaskan rakyat Indonesia. Perjuangan ini sebagai upaya

\footnotetext{
${ }^{18}$ Ibid, h. 104-105.

${ }^{19}$ Bunyamin Mahtuh, Internalisasi Nilai-Nilai Pancasila dan Nasionalisme Melalui Pendidikan Kewarganegaraan, Jurnal EDUCATIONIST. Vol. II No. 2 Juli 2008, h. 134.

${ }^{20}$ Aguk Irawan, Penakluk Badai...h. 201-202.
} 
menumbuhkan semangat nasionalisme rakyat Indonesia. Pada kutipan di atas terlihat penulis novel mengangkat sebuah gagasan bahwa tanggungjawab pendidikan harus dipikul bersama, harus ada kerjasama antara pemerintah dan para ulama dalam penyelenggaraan pendidikan di bumi pertiwi.

Pondok Pesantren sebagai model sistem pendidikan pertama dan tertua di Indonesia, keberadaannya mengilhami model dan sistem-sistem yang ditemukan saat ini. Bahkan model pondok pesantren tidak lapuk dimakan zaman dengan segala perubahannya. Karenanya banyak pakar, baik lokal maupun internasional melirik Pondok Pesantren sebagai bahan kajian. Tidak jarang beberapa tesis dan disertasi menulis tentang lembaga pendidikan Islam tertua ini. Pendidikan pesantren di Indonesia telah menjadi inspirasi bagi beberapa negara luar, bahkan pesantren justru lebih diperhatikan oleh negara luar dibandingkan negaranya sendiri. Pesantren di Indonesia minim perhatian pemerintah, pesantren hanya diperhatikan dan diperebutkan pada saat pemilu saja. Sebagaimana yang diungkapkan oleh K.H. Salahuddin Wahid bahwa:

"Selama ini, lembaga pendidikan swasta, terutama pondok pesantren, kurang mendapat perhatian pemerintah. Sehingga banyak pesantren terbelakang. Padahal setiap pemilu, para calon presiden dan calon wakil presiden selalu berebut untuk mendatangi pesantren guna mendapatkan dukungan para kiai dan santri.",21

Novel Penakluk Badai karya Aguk Irawan MN menggambarkan tentang nasionalisme para pejuang kemerdekaan negara Indonesia. Dalam novelnya ini Aguk lebih banyak menceritakan nasionalisme K.H. Hasyim Asy’ari, tokoh agama juga pahlawan kemerdekaan Republik Indonesia. Nasionalisme para pejuang ini diawali dengan perjuangan mencerdaskan rakyat Indonesia, kemudian mengupayakan gerakan-gerakan perlawanan terhadap ketidakadilan para kolonial pemerintahan Hindia-Belanda pada rakyat Indonesia. Sebagaimana kutipan berikut:

"Perkembangan pendidikan dengan sistem madrasah di Tebuireng membuat tokoh-tokoh muda cemerlang, seperti Soekarno dan Hatta,datang

\footnotetext{
${ }^{21}$ Sunariyah “Jadi Rebutan Saat Pemilu, Pondok Pesantren Minim Perhatian”, Berita Liputan6.com 1 Juli 2014. Terarsip di: http://indonesia-baru.liputan6.com/read/2071346/jadirebutan-saat-pemilu-ponpes-minim-perhatian-pemerintah. (Online: 24 Januari 2015)
} 
berkunjung. Mereka datang untuk membicarakan masalah kebangsaan. Pada tahun 1921, datang pula Tan Malaka dan Semaun (wakil ISDV) ke tebuireng. Dari pertemuan singkat itulah diperoleh kesepakatan bahwa mereka akan sama-sama berjuang mencerdaskan rakyat Indonesia, mengupayakan gerakan-gerakan perlawanan terhadap ketidakadilan seperti yang dilakukan para buruh terhadap pemerintahan Hindia Belanda lewat VSTP dan aksi-aksi pemogokan, disertai selebaran-selebaran sebagai alat propaganda, agar rakyat dapat melihat ketidakadilan yang diterima oleh kaum buruh". 22 "Tak lama kemudian, K.H. Hasyim Asy'ari tak ragu-ragu menyerukan kepada penduduk Jombang, agar mereka tidak larut dalam pekerjaan di Pabrik Gula, Diwek-Cukir, milik Hindia Belanda. Ia memimpin sendiri gerakan untuk menghentikan penyewaan tanah pribumi pada kaum penjajah. Juga gerakan mogok kerja. Tahun itu adalah tahun kobaran api, semangat menentang imperialisme dari segala penjuru". ${ }^{23}$

Kutipan di atas mendekripsikan tentang kesepakatan yang diperoleh dari pertemuan para pejuang, yaitu Soekarno, Tan Malaka, dan K.H. Hasyim Asy'ari. Dari pertemuan tersebut diperoleh kesepakatan bahwa mereka akan bersamasama berjuang mencerdaskan rakyat Indonesia, mengupayakan gerakan-gerakan perlawanan terhadap ketidakadilan seperti yang dilakukan para buruh terhadap pemerintahan Hindia Belanda lewat VSTP dan aksi-aksi pemogokan, disertai selebaran-selebaran sebagai alat propaganda, agar rakyat dapat melihat ketidakadilan yang diterima oleh kaum buruh.

Selanjutnya dalam novel ini Aguk menceritakan tindakan K.H. Hasyim Asy'ari sebagai wujud nasionalismenya, dengan spirit pembebasan ia menyerukan kepada penduduk Jombang, agar mereka tidak larut dalam pekerjaan di Pabrik Gula milik Hindia Belanda. Ia sendiri yang memimpin gerakan untuk menghentikan penyewaan tanah pribumi pada kaum penjajah. Dan ia juga mengawal gerakan mogok kerja para buruh.

Cerita novel Penakluk Badai pada halaman 202 di atas seakan memperingatkan kepada para nahdiyin, khususnya para pengurus organisasi Nahdlatul Ulama (NU) bahwa hendaknya para pengurus NU untuk melakukan evaluasi kritis terhadap komitmen pembebasan NU pada problem sosial masyarakat. Seperti apa yang telah dilakukan kiai Hasyim. Pada saat ini terdapat

\footnotetext{
${ }^{22}$ Aguk Irawan, Penakluk Badai...h. 202.

${ }^{23}$ Ibid,h. 203 .
} 
banyak problem sosial masyarakat di Indonesia, misalnya kasus kolonialisasi tembakau yang terjadi di Madura. Masyarakat Madura yang notabenenya adalah mayoritas warga NU, sepertinya dibiarkan berada dalam belitan kolonialisasi yang terselubung akibat politik ekonomi yang dimainkan oleh pemilik modal. Hal inilah yang selama ini masih belum mendapat perhatian dari NU. ${ }^{24}$

Perjuangan melawan para penjajah dilakukan K.H. Hasyim Asy’ari dalam bentuk perjuangan nasionalisme religius. Nasionalisme religius yang penulis maksud adalah paham kebangsaan yang dilandasi oleh nilai dan semangat keagamaan. Artinya agama menjadi suatu spirit dan nilai untuk menegakkan suatu negara yang adil dan makmur. Dengan kata lain, hubungan agama dan negara bisa bersifat simbiotik mutualisme yang saling menguntungkan. Gambaran perjuangan nasionalisme religius K.H. Hasyim Asy'ari dapat dilihat pada kutipan berikut:

“Bentuk perjuangan nasionalisme religius K.H. Hasyim Asy'ari Asy'ari antara lain juga dengan memberikan fatwa haram bagi pribumi muslim yang menyanyikan lagu kebangsaan Kimigayo dan mengibarkan bendera Hinomaru dan segala bentuk Niponisasi (serba Jepang). Hari berikutnya, K.H. Hasyim Asy'ari menyerukan semua pribumi yang bekerja di Pabrik Gula yang sudah dikuasai Jepang, untuk mogok kerja, hingga ekonomi lumpuh beberapa hari karena ulah mogok kerja itu." 25

Dalam novel Penakluk Badai, Aguk Irawan menggambarkan nasionalisme K.H. Hasyim Asy'ari Asy'ari sebagai tokoh utama dalam novel tersebut, namun ia juga melibatkan tokoh-tokoh yang berperan penting dalam proses kemerdekaan Republik Indonesia seperti Soekarno, Moh. Hatta, Tan Malaka, Soedirman dan Wahid Hasyim. K.H. Hasyim Asy'ari sebagai tokoh utama digambarkan sebagai sosok penting dalam proses kemerdekaan Republik Indonesia, dimana ia selalu menanamkan nasionalisme kepada masyarakat Indonesia.

K.H. Hasyim Asy’ari adalah ulama terkemuka di Indonesia. oleh karena itu, beliau lebih dekat dengan rakyat dan nasehat beliau akan mudah diterima rakyat. Terbukti ketika beliau memfatwakan jihad (melawan penjajah) kepada masyarakat

\footnotetext{
${ }^{24}$ Tim PW. LTN-NU Jawa Timur, Sarung dan Demokrasi untuk Peradaban KeIndonesiaan, Surabaya: Khalista, 2008, h. 7.

${ }^{25}$ Aguk Irawan MN, Penakluk Badai..., h. 344.
} 
Indonesia, masyarakat Indonesia pun berperang melawan para penjajah. Sebagaimana kutipan berikut:

"Karena kehidupan rakyat pribumi semakin memburuk K.H. Hasyim Asy'ari kembali mengeluarkan fatwa jihad di Soeara Nahdlatoel Oelama. Dan pekik itu seperti gayung bersambut, dan menggerakkan tokoh-tokoh lokal untuk memanggul senjata, bergerilya dengan cara masing-masing. Perlawanan rakyat di beberapa tempat pun meledak." ${ }^{26}$ "Kemerdekaan negara kita statusnya sah secara fikih. Karena itu, umat Islam wajib berjihad untuk mempertahankannya" ".Perang berkecamuk diseluruh negeri. Bara di bumi Indonesia. fatwa yang dicetuskan oleh K.H. Hasyim Asy'ari seakan memberikan daya yang sangat dahsyat untuk menggerakkan barisan-barisan para pemuda bangsa. Apalagi para santri K.H. Hasyim Asy'ari Asy'ari yang tergabung dalam komando Sabilillah dan Hizbullah. Dengan pekik takbir dan harapan untuk tetap gagah berdiri dengan menggenggam kemerdekaan membuat gelora untuk menempuh kesyahidan semakin nyata.,27

Kutipan di atas menggambarkan bagaimana reaksi rakyat pribumi terhadap fatwa jihad yang dikeluarkan K.H. Hasyim Asy'ari di Soeara Nahdlatoel Oelama. Hal itu dalam rangka untuk merespon sikap sekutu yang arogan dan kembali ingin menjajah bangsa Indonesia, sehingga K.H. Hasyim Asy’ari atas nama pengurus besar NU memfatwakan seruan jihad fi sabilillah kepada setiap muslim untuk membela negara Indonesia sampai titik darah penghabisan. Adapun bunyi fatwa tersebut yakni: ${ }^{28}(1)$. Kemerdekaan Indonesia yang diproklamasikan pada tanggal 17 Agustus 1945 wajib dipertahankan. (2). Republik Indonesia sebagai satusatunya pemerintahan yang sah, wajib dibela dan diselamatkan (3). Musuh Republik Indonesia, terutama Belanda yang datang kembali dengan membonceng tugas-tugas tentara sekutu (Inggris) dalam masalah tawanan perang bangsa Jepang tentulah akan menggunakan kesempatan politik dan militer untuk kembali menjajah Indonesia. (4). Umat Islam terutama Nahdlatul Ulama wajib mengangkat senjata melawan Belanda dan kawan-kawannya yang hendak kembali

\footnotetext{
${ }^{26}$ Aguk Irawan MN, Penakluk Badai..., h. 349.

${ }^{27}$ Ibid, h. 457.

${ }^{28}$ Ibid, h. 411.
} 
menjajah Indonesia. (5). Kewajiban tersebut adalah jihad yang menjadi kewajiban tiap-tiap orang Islam ( fardhu 'ain) yang berada pada jarak radius 94 km (jarak di mana umat Islam diperkenankan sembahyang jama' dan qasar). Adapun mereka yang berada di luar jarak tersebut berkewajiban membantu saudara-saudaranya yang berada dalam jarak radius $94 \mathrm{~km}$ tersebut.

Dalam novel "Penakluk Badai", Aguk Irawan menggambarkan nasionalisme kiai Hasyim Asy’ari sebagai tokoh utama dalam novel tersebut, namun ia juga melibatkan tokoh-tokoh yang berperan penting dalam proses kemerdekaan Republik Indonesia seperti Soekarno dan Moh. Hatta. Selain itu Aguk juga melibatkan beberapa organisasi, seperti Nahdlatul Syubban, Pemuda Muslim dan PETA. Kiai Hasyim sebagai tokoh utama digambarkan sebagai sosok penting dalam proses kemerdekaan Republik Indonesia, dimana ia selalu menanamkan nasionalisme kepada masyarakat Indonesia.

Kiai Hasyim adalah ulama terkemuka di Indonesia. oleh karena itu, beliau lebih dekat dengan rakyat dan nasehat beliau akan mudah diterima rakyat. Terbukti ketika beliau memfatwakan jihad (melawan penjajah) kepada masyarakat Indonesia, masyarakat Indonesia pun berperang melawan para penjajah. Sebagaimana kutipan berikut:

"Karena kehidupan rakyat pribumi semakin memburuk kiai Hasyim kembai mengeluarkan fatwa jihad di Soeara Nahdlatoel Oelama. Dan pekik itu seperti gayung bersambut, dan menggerakkan tokoh-tokoh lokal untuk memanggul senjata, bergerilya dengan cara masing-masing. Perlawanan rakyat di beberapa tempat pun meledak." 29

"Kemerdekaan negara kita statusnya sah secara fikih. Karena itu, umat Islam wajib berjihad untuk mempertahankannya"

Kutipan tersebut menggambarkan bagaimana reaksi rakyat pribumi terhadap fatwa jihad yang dikeluarkan kiai Hasyim di Soeara Nahdlatoel Oelama. Hal itu dalam rangka untuk merespon sikap sekutu yang arogan dan kembali ingin menjajah bangsa Indonesia, sehingga kiai Hasyim atas nama pengurus besar NU memfatwakan seruan jihad fi sabilillah kepada setiap muslim untuk membela negara Indonesia sampai titik darah penghabisan. Fatwa jihad yang dicetuskan

\footnotetext{
${ }^{29}$ Aguk Irawan MN, Penakluk Badai..., h. 349.
} 
oleh kiai Hasyim mampu membangkitkan semangat juang para generasi bangsa. Fatwa tersebut mampu menggerakkan barisan-barisan para pemuda bangsa. Sebagaimana kutipan berikut:

"Perang berkecamuk diseluruh negeri. Bara di bumi Indonesia. fatwa yang dicetuskan oleh kiai Hasyim seakan memberikan daya yang sangat dahsyat untuk menggerakkan barisan-barisan para pemuda bangsa. Apalagi para santri kiai Hasyim Asy'ari yang tergabung dalam komando Sabilillah dan Hizbullah. Dengan pekik takbir dan harapan untuk tetap gagah berdiri dengan menggenggam kemerdekaan membuat gelora untuk menempuh kesyahidan semakin nyata." 30

Kutipan tersebut menggambarkan bagaimana efek dari fatwa jihad yang dicetuskan kiai Hasyim. Fatwa jihad yang dicetuskan oleh kiai Hasyim memberikan motivasi yang sangat dahsyat untuk menggerakkan barisan-barisan para pemuda bangsa, sehingga perang berkecamuk di seluruh negeri. Jihad berarti perjuangan sungguh-sungguh dengan mengerahkan segala potensi dan kemampuan yang dimiliki untuk mencapai tujuan, khususnya dalam mempertahankan kebenaran, kebaikan dan keluhuran, atau mengajak kepada agama yang benar. ${ }^{31}$

Sebagai tokoh ulama tersohor kiai Hasyim banyak dimintai nasehat ataupun pendapat. Bahkan tokoh nasionalis seperti Soekarno dan Hatta juga meminta pendapat beliau tentang strategi melawan penjajah.

"Soekarno dan Hatta suatu ketika berkunjung ke Tebuireng untu meminta pendapat pada kiai Hasyim, mengenai langkah-langkah apa yang seharusnya dilakukan oleh seluruh lapisan bangsa. Lalu Kiai Hasyim menyerahkan strategi perang kepada Soekarno dan Hatta, agar PETA yang sudah lama didirikan beberapa pihak terutama oleh kalangan pesantren untuk diaktifkan." 32

Sosok Soekarno sebagai tokoh nasionalis selalu menghargai tokoh pesantren seperti kiai Hasyim, begitu pula tokoh pesantren juga selalu menghargai tokoh nasionalis. Dalam suatu pertemuan para tokoh bangsa kiai ditanya tentang apa yang harus diperbuat terkait dengan kekuasaan dan kekejaman sekutu, dalam

\footnotetext{
${ }^{30}$ Ibid, h. 457.

${ }^{31}$ Ma'had Aly, Fiqh Realitas, Yogyakarta ; Pustaka Pelajar, 2005, h. 103.

${ }^{32}$ Aguk Irawan MN, Penakluk Badai..., h. 307.
} 
pertemuan tersebut kiai meminta pendapat kepada bung Karno.Sebagaimana kutipan berikut:

"Bagaimana Kang Mas Karno? Tanya kiai Hasyim sambil menoleh kea rah Bung Karno.

"Menurut saya, kalau Jepang benar-benar sudah takluk di tangan sekutu,kita buat perhitungan. Kalau Jepang dibekuk sekutu, berarti pemerintahan kita kososng. Karena di antara kita dan sebagian besar pribumi sudah bisa menulis dan membaca, juga tahu seluk-beluk administrasi Negara, kita harus mengambil alih kekuasaan."kata Soekarno.

Dalam novel Penakluk Badai tokoh Soekarno digambarkan sebagai tokoh nasionalis yang selalu menghargai pendapat ulama yang umumnya bagian dari kelompok Islam tradisional. Selain itu, Aguk juga menggambarkan sisi buruk Soekarno dalam keputusannya bersama Sjahrir untuk berkompromi dengan sekutu. Hal ini dapat dilihat dalam kutipan percakapan berikut:

"Bagaimana kiai, Tuan Syjahrir telah membuat keputusan sendiri?" Tanya Bung Tomo(Soetomo) kepada kiai Hasyim.

"Kesalahan pertama ada di Bung Karno (Soekarno)," sela Mas Mansyur.

"Masalahnya adalah pemerintah kita tidak yakin dengan kekuatan sendiri." Tambah Bung Tomo.

"Kalau seperti ini, rasa-rasanya pemerintah kita telah berkhianat pada hati nurani rakyat!" Dengan sedikit emosi kiai Wahab Hasbullah mengeluarkan kata-kata. $^{33}$

Kutipan percakapan di atas menggambarkan suasana yang memanas di kantor NU Surabaya. Pertemuan para tokoh bangsa tersebut adalah untuk membicarakan sikap Sjahrir yang berkompromi dengan sekutu, khususnya Belanda. Pada kutipan di atas Aguk menggambarkan Soekarno dan Sjahrir sebagai tokoh yang berkhianat pada bangsanya.

Novel Penakluk Badai ini juga melibatkan tokoh Abdul Wahid Hasyim selaku anak dari kiai Hasyim. Abdul Wahid digambarkan sebagai tokoh bangsa yang juga terlibat dalam proses kemerdekaan negara Republik Indonesia. Dalam proses pembentukan dasar Negara Indonesia, dia digambarkan sebagai tokoh utama, karena usulannya tentang Piagam Madinah langsung disetujui oleh tokohtokoh bangsa saat itu. Sebagaimana kutipan berikut:

\footnotetext{
${ }^{33} I b i d$, h. 434.
} 
"Ditengah-tengah perdebatan itulah Abdul Wahid Hasyim tampil sebagai penengah antara Muhammad Yamin dan Soekarno. Dengan pelan dan santun ia mengemukakan kandungan dan perjanjian Piagam Madinah yang terdiri dari 47 pasal. Abdul Wahid Hasyim juga merinci satu persatu pasal dari Piagam Madinah tersebut kedua kubu yang bersebrangan terdiam setelah menyimak penjelasan putra kiai Hasyim Asy'ari itu. Lalu Soekarno berpendapat "saya sangat terinspirasi oleh Piagam Madinah tersebut. Dan kiranya tuan-tuan setuju inilah jalan tengahnya. Kita ambil lima dasar untuk negara kita dari 47 pasal Piagam Madinah tersebut.",34

Kutipan di atas menggambarkan suasana politik nasional yang memanas lantaran terjadinya pertentangan kelompok dalam menentukan ideologi negara. Pada sidang BPUPKI 28 Mei-1 Juni 1945, kubu yang didalangi Soekarno dan Soepomo menghendaki negara ini bercorak nasionalis sekuler. Sedangkan kubu yang dikomando oleh Muhammad Yamin menginginkan Islam sebagai landasan dasar negara Indonesia. Kedua kubu ini masih terus saling menguatkan pandangan masing-masing, sehingga nasib Indonesia masih di ambang kesuraman, apakah dijadikan negara sekuler atau negara Islam.

Pertentangan tersebut baru reda setelah hadirnya Abdul Wahid Hasyim putra kiai Hasyim Asy’ari. Beliau yang sudah menerima gagasan dari ayahnya, tampil sebagai penengah dan mempertemukan dua kubu yang bertentangan itu. Wahid Hasyim menyampaikan pesan-pesan dari ayahnya bahwa kondisi sosial politik bangsa Indonesia ketika itu persis dengan kondisi Madinah pada masa Rasulullah. Karena itulah, ideologi negara yang tercantum dalam Piagam Madinah layak untuk dijadikan contoh dalam merumuskan ideologi negara Indonesia. Mendengar penjelasan dari Wahid Hasyim, kubu Soekarno dan kubu M. Yamin sama-sama menerima usulan tersebut. ${ }^{35}$ Secara tidak langsung, kiai Hasyim Asy'ari adalah dalang di balik tercetusnya ideologi negara Indonesia, dan berkat gagasannya itu pertentangan ideologi dapat diredakan.

Dalam novel Penakluk Badai ini Aguk Irawan juga mencantumkan beberapa organisasi yang terlibat dalam perjuangan kemerdekaan Republik

\footnotetext{
${ }^{34} I b i d$, h.387-388.

${ }^{35}$ Ibid, h. 386-387.
} 
Indonesia, yaitu organisasi PETA dan Nahdlatul Syubban. Hal ini dapat dilihat pada kutipan berikut:

"Keterbelakangan ekonomi, lemahnya mentalitas bangsa Indonesia memberi kesan tersendiri bagi generasi terpelajar bangsa Indonesia. hal ini juga dapat dipahami dari keinginan para pelajar untuk mengeluarkan bangsa ini dari berbagai keterpurukan tersebut. Langkah yang dilakukan oleh generasi terpelajar tersebut adalah mendirikan berbagai organisasi pendidikan dan pergerakan pembebasan, bernama Nahdlatul Syubban, organisasi Pemuda Muslim, yang diharapkan bahu-membahu dengan PETA",36

Kutipan di atas menggambarkan bagaimana langkah yang dilakukan oleh generasi terpelajar yaitu, mendirikan berbagai organisasi pendidikan dan pergerakan pembebasan, bernama Nahdlatul Syubban, organisasi Pemuda Muslim, yang bahu-membahu dengan PETA. Secara umum Aguk Irawan menggunakan bahasa yang bersifat persuasif, instruktif dan naratif. Bahasa yang bersifat persuasif tergambar dalam kutipan sebagai berikut:

"Wahai engkau generasi muda, seharusnya engkau bisa menghormati generasi tua, dan generasi tua seharusnya bisa lebih mencintai generasi muda. Marilah kita berjabat tangan, berpelukan kembali, dan setelah itu kita rapatkan barisan untuk melawan musuh bersama." 37

Gaya bahasa di atas merupakan bahasa persuasif di mana dalam kata atau kalimat yang bercetak tebal tersebut menjukkan bahwa seseorang berusaha menyakinkan atau memengaruhi orang lain, untuk bersatu dalam melawan musuh. Dalam kutipan di atas seseorang sedang menengahi dua kelompok yang berseberangan, yaitu kelompok generasi muda dan generasi tua. Padahal pada saat itu mereka seharusnya bersatu dan merapatkan barisan untuk melawan musuh yaitu para penjajah bumi pertiwi. Kalimat atau kata yang menggunakan gaya bahasa persuasif juga tergambar pada kutipan berikut:

"Janganlah hal-hal kecil dan sepele menyebabkan kita bercerai-berai, bertengkar dan saling bermusuhan di antara saudara sendiri. Janganlah kalian teruskan budaya saling mencaci dan membenci. Sebab agama kita adalah satu, yaitu Islam, mazhab kita Syafi' I, daerah kita satu; Jawa, dan

\footnotetext{
${ }^{36}$ Ibid, h. 235.

${ }^{37}$ Aguk Irawan MN, Penakluk Badai..., h.328.
} 
kita semua adalah ahlusunnah waljama'ah yang hidup dalam kesatuan Nusantara. Ada yang lebih penting untuk kita pikirkan, yaitu jalan menuju kemerdekaan. Wahai kaum muslimin, di tengah-tengah kalian orang-orang kafir telah merambah ke segala penjuru negeri, maka siapakah dari kalian yang mau bangkit untuk berjihad dan peduli untuk membimbing mereka ke jalan petunjuk? Mari kita bersatu, menyingsingkan lengan baju untuk mengambil hak kita, merebut kemerdekaan, yang sudah lama diambil penjajah. Ingatlah, setiap muslim wajib berjihad, dalam jarak dan radius kurang lebih $80 \mathrm{KM}$ dari markas penjajah... 38

Pada kutipan di atas gaya bahasa yang digunakan ialah persuasif, dimana seseorang mengajak untuk bersama-sama bersatu dalam merebut kemerdekaan. Kalimat kedua pada kalimat yang bercetak tebal di atas menunjukkan gaya bahasa instruktif. Pada kalimat itu, kiai Hasyim menginstruksikan kepada setiap muslim untuk berjihad melawan penjajah . Kutipan di atas merupakan kutipan pidato kiai Hasyim Asy'ari pada Muktamar ke 5 NU yang dilaksanakan di Pekalongan. Sementara itu bahasa instruktif juga tergambar dalam kutipan berikut:

"Saudara-saudarku seiman dan sebangsa, para murid dan santri-santri. Tak semua orang diberi kesempatan berjihad di jalan Allah. Karena itu berlatihlah sungguh-sungguh, karena nasib bangsa yang besar ini ada di pundak kalian. Berjuanglah hingga titik darah penghabisan, hidup atau mati. Karena keduanya membawa kebaikan untuk kita bersama. Tiada yang sia-sia." 39

Gaya bahasa di atas merupakan gaya bahasa instruktif, di mana seseorang memberikan arahan kepada saudara-saudara, para murid dan santri-santrinya untuk berlatih dengan sungguh-sungguh dan berjuang hingga titik darah penghabisan demi membela bangsa dan agamanya. Selain itu kalimat yang menggunakan gaya bahasa instruktif juga dapat dilihat pada kutipan berikut:

"Rakyat Surabaya! Keadaan genting! Tetapi saya peringatkan sekali lagi, jangan mulai menembak, baru kalau kita ditembak, maka kita mulai menyerang mereka itu kita tunjukkan bahwa kita ini adalah benar-benar orang yang ingin merdeka.." 40

Gaya bahasa instruktif pada kutipan di atas menunjukkan sesorang yang menginstruksikan kepada rakyat Surabaya agar tidak menyerang terlebih dahulu.

\footnotetext{
${ }^{38}$ Ibid, h.311.

${ }^{39}$ Ibid, h.368.

${ }^{40}$ Ibid, h. 419.
} 
Meskipun pada saat itu keadaan sudah sangat genting. Kutipan di atas adalah instruksi dari Bung Tomo sebagai tokoh anak muda Surabaya. Instruksi tersebut disampaikan ketika ia telah menerima fatwa jihad dari kiai Hasyim dan NU, dan instruksi tersebut disampaikan di depan kantor Hizbullah Surabaya. Instruksi ini juga disiarkan oleh banyak radio, termasuk RRI.

Selain menggunakan bahasa persuasif, dan instruktif, Aguk Irawan juga menggunakan bahasa naratif yang tergambar dalam kutipan di bawah ini :

"Dalam waktu yang hampir bersamaan, perlawanan rakyat yang dipimpin oleh Pang Suma berkobar di Kalimantan Selatan. Pang Suma adalah pemimpin suku Dayak berpengaruh di kalangan suku-suku di aderah Tayan dan Meliau. Perlawanan ini bersifat gerilya untuk mengganggu aktivitas Jepang di Kalimantan. Momentum perlawanan Pang Suma diawali dengan pemukulan seorang tenaga kerja Dayak oleh pengawas Jepang. Kejadian ini kemudian memulai rangkaian perlawanan yang mencapai puncaknya dalam sebuah serangan balasan Dayak yang dikenal dengan Perang Majang Desa, dari April hingga Agustus 1944 di daerah Tayan-Meliau-Batang Tarang (Kab. Sanggau). Sekitar 600 pejuang kemerdekaandibunuh oleh Jepang, termasuk Pang Suma." $" 41$

Teks di atas menggunakan gaya bahasa naratif, di mana Aguk Irawan menggambarkan tentang perlawanan rakyat yang dipimpin oleh Pang Suma di Kalimantan Selatan. Dan perlawanan ini berakhir dengan perang dinamakan Perang Majang Desa. Pada teks di atas Aguk secara rinci menarasikan perlawanan yang terjadi di Kalimantan Selatan tersebut.

\section{E. Kesimpulan}

Berdasarkan hasil temuan terhadap tiga unit analisis Halliday. Dapat penulis simpulkan: Pertama, medan wacana dalam novel Penakluk Badai, secara umum berkaitan dengan nasionalisme para pejuang kemerdekaan negara Republik Indonesia, yang dimanifestasikan dengan pendidikan bagi kaum pribumi (sebagai upaya perjuangan dalam mencerdaskan kehidupan anak bangsa), dan perlawanan terhadap kolonialisme. Kedua, pelibat wacana dalam novel tersebut melibatkan tokoh-tokoh yang berperan penting dalam proses kemerdekaan Republik

\footnotetext{
${ }^{41}$ Ibid, h. 373.
} 
Indonesia seperti kiai Hasyim Asy'ari, Soekarno, Moh. Hatta, Soedirman dan Abdul Wahid Hasyim. Ketiga, mode wacana secara umum bersifat instruktif, naratif dan persuasif.

Hasil penelitian penulis tentang teks novel Penakluk Badai karya Aguk Irawan $\mathrm{MN}$, secara umum dapat ditarik kesimpulan bahwa Aguk Irawan mengkonstruksikan wacana nasionalisme itu berdasarkan atas dokumen sejarah kemerdekaan Republik Indonesia, yang dikemas dengan bahasa sastra melewati novel bigrafi K.H. Hasyim Asy'ari. Aguk Irawan menggambarkan nasionalisme dalam bentuk upaya mengusir para penjajah, baik itu dengan memberikan pendidikan nasionalisme kepada generasi bangsa, menyemangati seluruh elemen bangsa, ataupun mengusir penjajah dengan cara mengangkat senjata.

\section{Daftar Pustaka}

Aliah Darma, Yoce, Analisis Wacana Kritis, Bandung:Yrama Widya, 2009.

Alexander, Bonafacio, dan Yetik Wulandari, Kamus Poket Bahasa Indonesia, Yogyakarta:Aksara Sukses, 2014.

Departemen Pendidikan Nasional, Kamus Besar Bahasa Indonesia, Edisi ke 3, Jakarta:Persero Balai Pustaka, 2005.

Efendi, Anwar, "Gagasan Nasionalisme dan Wawasan Kebangsaan dalam Novel Indonesia Modern", staff.uny.ac.id/sites/default/files/Wawasan\%20Kebangsaan.doc. (Online 27 Agustus 2014)

Eriyanto, Analisis Wacana Pengantar Analisis Teks Media, Yogyakarta:LkiS, 2006.

Faisal,Sanapiah, Pengumpulan dan Analisa Data dalam Penelitian Kualitatif, dalam Burhan Bungin, "Analisis Data Penelitian Kualitatif: Pemahaman Filosofis dan Metodologis ke Arah Penguasaan Model Aplikasi”, Jakarta: PT Raja Grafindo Persada, 2003.

Fuad Yusuf,Choirul, dkk., Isu-Isu Sekitar Madrasah, Jakarta: Puslitbang Pendidikan Agama dan Keagamaan Badan Litbang dan Diklat Departemen Agama RI, 2006, h. 3.

Irawan M.N., Aguk, Penakluk Badai, Depok: Global Media, 2012.

Hendrastomo, Grendi, Nasionalisme Vs Globalisasi, DIMENSIA Volume I No. 1, Maret 2007. 
Hidayatullah,Yusuf, Nasionalisme dalam Novel (Analisis Wacana Tentang Nasionalisme Dalam Novel Bumi Manusia Karya Pramoedya Ananta Toer), Terarsif di: Http://Www.Jurnalkommas.Com/Docs/Yusuf\%20hidayatullah\%20d12100 88\%20.Pdf. (Online:Senin 9 Februari 2015)

http://ppalfurqonsanden.info/berita-148-pondok-pesantren-sebagai-alternatifpendidikan-berkarakter--di-indonesia.html

Ihwal Nilai Nasionalisme dan Buku Elektronik serta Silabus, Perpustakaan Universitas Pendidikan Indonesia, pdf 2/14, h. 13. (online: 24 Januari 2013).

Inneke Widhiastuti, Cristina, "Represesntasi Nasionalisme dalam Film Merah Putih ;AnalisisSemiotika Roland Barhtes", Skripsi, Serang:Universitas Sultan Ageng Tirtayasa, 2012, t.d.

Jainuri, Ahmad, Islam, Nasionalisme dan Keindonesiaan, MA'ARIF Volume 03 No. 02 Mei 2008.

Jariah, Ainun, "Nilai-Nilai Nasionalisme dalam Film Tanah Surga Katanya (Analisis Semiotika Roland Barthes)”, Skripsi, Palangka Raya: Sekolah Tinggi Agama Islam Negeri Palangka Raya, 2013, t.d.

Jorgensen, M. W., dan Phillips, L. J, Analisis Wacana Teori \& Metode, Yogyakarta:Pustaka Pelajar, 2010.

Jumat, Gani, Nasionalisme Ulama: Pemikiran Politik Kebangsaan Sayyid Idrus bin Salim Aljufriy 1891-1969, Jakarta: Kementrian Agama RI, 2012.

Kriyantono, Rachmat, Teknik Praktis Riset Komunikasi, Jakarta:Kencana Prenada Media Group, 2006.

Mahtuh,Bunyamin, Internalisasi Nilai-Nilai Pancasila dan Nasionalisme Melalui Pendidikan Kewarganegaraan, EDUCATIONIST. Volume II No. 2 Juli 2008.

Maschan Moesa, Ali, Nasionalisme Kiai Konstruksi Sosial Berbasis Agama, Yogyakarta: LKiS, 2007

Mulyono, "Nasionalisme dan Refleksi Sejarah Indonesia Novel Burung-Burung Manyar (BBM) karya Y.B. Mangunwijaya (YBM)”, Tesis, Surakarta:Universitas Negeri Surakarta, 2008, t.d.

Mustaqim, Abdul, Bela Negara dalam Perspektif Al-Qur'an (Sebuah Tranformasi Makna Jihad), Analisis Volume XI, Nomor 1, Juni 2011.

Muslih, Muhammad, Filsafat Ilmu:Kajian atas Asumsi Dasar, Paradigma dan Kerangka Teori Ilmu Pengetahuan, Yogyakarta:Belukar, 2007.

M. Kusasi, "Perhatian Pemerintah Terhadap Pondok Pesantren", 4 Desember 2013, terarsip di : http://kaltim.kemenag.go.id/index.php?a=artikel\&id=22574. (Online: 25 Februari 2015). 
Niam, Mukafi, "Kurang Perhatian Pemerintah Pesantren Salafiyah Bentuk MPS”, Berita NU Online 22 Juli 2011. Terarsip di: http://www.nu.or.id/a,public-m,dinamic-s,detail-ids,1-id,32677-lang,idc, warta,Kurang+Perhatian+Pemerintah++Pesantren+Salafiyah+Bentuk+M PS-.phpx. (Online: 24 Februari 2015).

Pawito, Penelitian Komunikasi Kualitatif, Yogyakarta:LKiS, 2007.

Pimpinan MPR RI dan Tim Kerja Sosialisasi MPR Periode 2009-2014, Empat Pilar Kehidupan Berbangsa dan Bernegara, Jakarta:Sekretariat Jenderal MPR RI, 2012

Purwandari, Retno dan Qoni'ah, Buku Pintar Bahasa Indonesia, Yogyakarta:Familia, 2012.

Qodir, Abdul, dkk, Pedoman Penulisan Skripsi, Palangka Raya:Sekolah Tinggi Agama Islam Negeri Palangka Raya, 2013.

Ramadhan, Muhammad Ali, "Stop Diskriminasi Pendidikan di Indonesia". Berita : 11 Agustus 2014. Terarsip di: http://edukasi.kompasiana.com/2014/08/11/stop-diskriminasi-pendidikandi-indonesia-668060.html. (Online: 25 Februari 2015)

Ramayulis dan Samsul Nizar, Ensiklopedi Tokoh Pendidikan Islam, Ciputat:QUANTUM TEACHING, 2005.

Revita, Ike, Konsep-Konsep Dasar dalam Analisis Wacana, terarsip di: repository.unand.ac.id/2385/1/JurnalAdabbiyat1.doc. (Online: Senin, 24 Maret 2014).

Riswandi, Ilmu Komunikasi, Jakarta: Graha Ilmu, 2009.

$R$ Suyoto Bakir dan Sigit Suryanto, Kamus Lengkap Bahasa Indonesia Edisi Terbaru, Tanggerang:Karisma Publishing Group, 2009.

Saiful "Ashabiyah dari filsafat Sejarah ke Filsafat Politik: Telaah atas Kitab Muqaddimah Ibnu Khaldun”, terarsip di, http://ifuljihad.blogspot.com/2009/02/ashabiyah-dari-filsafat-sejarah.html. (Online: 27 Agustus 2014)

Santoso, Anang, Jejak Halliday Dalam Lingustik Kritis dan Analisis Wacana kritis, terarsip di, http://sastra.um.ac.id/wp-content/uploads/2009/10/JejakHalliday-dalam-Linguistik-Kritis-dan-Analisis-Wacana-Kritis-AnangSantoso.pdf,(online: Senin, 24 Maret 2014).

Semi, Atar, Anatomi Sastra, Padang: Angkasa Raya, 1993.

Sjamsuddin, Nazaruddin. Sukarno Pemikiran Politik dan Kenyataan Praktek, Jakarta:CV.Rajawali, 1988.

Sobur, Alex, Analisis Teks Media, Bandung:Remaja Rosdakarya, 2006.

Srijanti dkk, Pendidikan Kewarganegaraan untuk Mahasiswa, Yogyakarta:Graha Ilmu, 2009. 
Sunariyah “Jadi Rebutan Saat Pemilu, Pondok Pesantren Minim Perhatian”, Berita Liputan6.com 1 Juli 2014. Terarsip di: http://indonesiabaru.liputan6.com/read/2071346/jadi-rebutan-saat-pemilu-ponpes-minimperhatian-pemerintah. (Online: 24 Januari 2015)

Surjaman, Tjun (ed), Metodologi Penelitian Kualitatif, Bandung:Remaja Rosdakarya, 2000.

Syahrial dkk, Membangun Karakter dan Kepribadian Melalui Pendidikan Kewarganegaraan, cet. Ke-I, Jakarta: Graha Ilmu, 2006.

Tim PW. LTN-NU Jawa Timur, Sarung dan Demokrasi untuk Peradaban KeIndonesiaan, Surabaya: Khalista, 2008.

Udjana Effendy, Onong, Ilmu Teori dan Filsafat Komunikasi, Bandung: Citra Aditya Bakti, 2000.

Wibowo, Timothy,Mewujudkan Pendidikan Karakter yang Berkualitas, terarsip di: http://www.pendidikankarakter.com/mewujudkan-pendidikan-karakteryang-berkualitas/. (Online: 24 Januari 2015) www.nu.or.id. 